\title{
Posterolateral Extrusion of C7-D1 Intervertebral Disc Associated with Intradiscal Hematoma
}

\section{Intradiskal Hematomla İişkili C7-D1 İtervertebral Disk Posterolateral Ekstrüzyonu}

Vijay JOSHI, Dattatraya MUZUMDAR, Amit MAHORE, Atul GOEL

Seth G.S. Medical College and King Edward VII Memorial Hospital, Department of Neurosurgery, Mumbai, India

Correspondence address: Dattatraya MUZUMDAR / E-mail: dmuzumdar@hotmail.com

\begin{abstract}
A case of an extruded cervical intervertebral disc at C7-D1 level with intradiscal hematoma in a 68-year-old male patient is presented. MR imaging showed a posterolateral extradural hemorrhagic lesion at C7-D1 level. It was suggestive of an epidural hematoma or a bleed within a neoplasm. A posterior approach was adopted and an extruded intervertebral disc with intradiscal hematoma was found and completely excised. Extruded cervical disc with intradiscal hematoma in a 68-year-old male has never been hitherto reported in the literature. The uniqueness of the case is the extruded cervical disc with hematoma within it presenting at an advanced age and unusual radiological features on MR imaging. The clinical presentation, radiological features and surgical management of this rare condition are discussed and the relevant literature is briefly reviewed.
\end{abstract}

KEYWORDS: Cervical intervertebral disc, Cervical spinal cord compression, Hematoma

Öz

68 yaşında erkek bir hastada intradiskal hematomla ilişkili C7-D1 seviyesinde ekstrüde bir servikal intervertebral disk olgusu sunulmuştur. MR görüntüleri C7-D1 seviyesinde posterolateral ekstradural hemorajik bir lezyon gösteriyordu. Bu bir epidural hematom veya neoplazi içine kanamayı destekliyordu. Posterior yaklaşım uygulandı ve intradiskal hematomla birlikte ekstrüde bir intervertebral disk bulundu ve tamamen çıkarıldı. Literatürde 68 yaşında bir erkek hastada intradiskal hematomla birlikte ekstrüde servikal disk hiç bildirilmemiştir. Bu vakanın özelliği ileri bir yaşta ortaya çıkması ve MR görüntülemede alışılmadık özelliklere sahip olmasıdır. Bu nadir durumun klinik prezentasyonu, radyolojik özellikleri ve cerrahi tedavisi tartışılmıştır ve ilgili literatür gözden geçirilmiştir.

ANAHTAR SÖZCÜKLER: Servikal intervertebral disk, Servikal spinal kord kompresyonu, Hematom

\section{INTRODUCTION}

Extruded interverterbal disc with epidural hematoma has been reported in the thoracic and lumbar region $(4,10)$. However, hematoma in an extruded intervertebral disc in the cervical region is rare and has hitherto never been reported in the literature. The common differential diagnoses in such a situation would be a nerve sheath tumour (10) or a spontaneous epidural hematoma. The pathogenesis and radiological features of an extruded intervertebral disc with intradiscal hematoma is discussed and the relevant literature is briefly reviewed.

\section{CASE REPORT}

A 68-year-old male patient presented with progressively worsening paraparesis and inability to hold objects in both hands for the past 15 days. There was no history of sensory complaints, ataxia or sphincteric complaints. There was no history of trauma or fever. On examination, he had spastic paraparesis grade 2 and intrinsic muscle weakness in both hands. There was no sensory level. Deep tendon reflexes were exaggerated. Plantars were bilaterally extensor. MRI of cervical spine was done which showed an extradural lesion at C7-D1 level, isointense with intradiscal hypointensity on T1weighted images and minimally hyperintense on T2-weighted images suggestive of a bleed within the intervertebral tissue (Figure 1). The lesion extended more on the right lateral aspect of the cervical spinal cord, displacing and compressing the spinal cord to the left side (Figure 2). Contrast enhancement revealed peripheral ring enhancement. The differential diagnosis included a hematoma or a bleed with within a neurinoma or meningioma. Routine hematological workup and investigations for bleeding disorders were within normal limits. The patient underwent a surgery through posterior approach. A C7- D1 laminectomy was performed. The lesion was firm in consistency and contained altered blood, with the wall of the lesion showing a xanthochromic appearance. It was consistent with an extruded cervical intervertebral disc. 
It was completely excised using curettes and biopsy forceps. The patient showed remarkable improvement in the post operative period. He was walking with support and could perform fine activities using his both hands. Histological exam showed degenerated intervertebral disc with hematoma

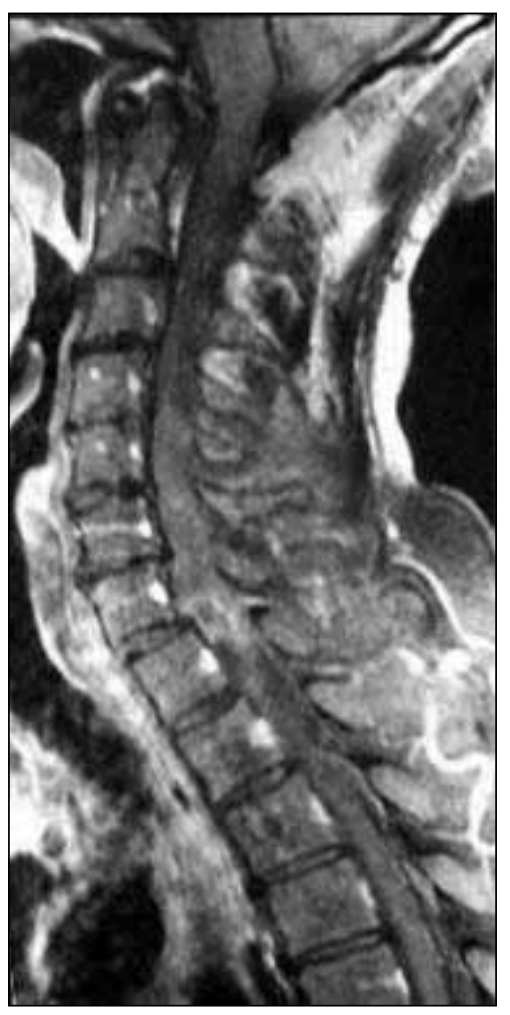

Figure 1: Sagittal T1 MR image showing an extradural lesion with hyperintense rim and hypointense center suggestive of extruded intervertebral disc with hematoma.

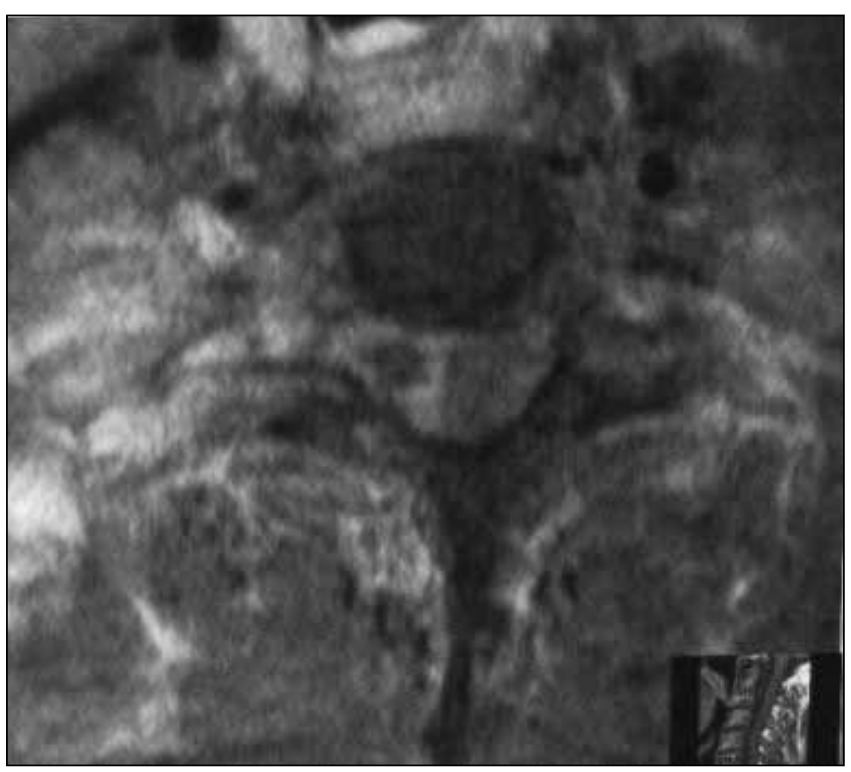

Figure 2: Axial T1 axial MR image showing a right sided extradural lesion with hyperintense rim and hypointense center suggestive of extruded intervertebral disc with hematoma displacing the cord towards left lateral side.
(Figure 3). At follow-up after 1 year, the patient is well and asymptomatic (Figure 4).

\section{DISCUSSION}

Degenerative disc disease of the cervical spine represents the anatomic adaptations to the continuous wear and tear of the involved bony and ligamentous structures. This process leads to the structural changes in the involved joints, with thickening and calcification of the ligaments and appositional bone formation (4). Radiological evidence of the cervical spondylosis is present in $25 \%$ to $50 \%$ of the population by age of 50 years and increases to $75 \%$ to $85 \%$ by age of 65 years (1-3). With ageing, there is qualitative and quantitative change in the proteins within the nucleus pulposus, and the water content of the disc drops from approximately $88 \%$ at infancy to approximately $70 \%$ at age of 72 (6). It weakens the annulus causing it to rupture and leading to acute disc herniation. Cervical disc herniation is common in the subaxial spine, more so at C5, 6 level. Extrusion of intervertebral disc at C7-D1 level is extremely rare and occurs in about $4 \%$ of all herniated cervical discs (9). Moreover, intradiscal hematoma is further rare and has never been reported earlier; however disc herniation at thoracic level with hematoma has been reported (8). Cervical intervertebral disc prolapse usually affects people in the fourth decade of life somewhat more frequently than individuals in other age groups. The male to female ratio is 1.4:1. Our patient was in the sixth decade of his life, which is unusual. The relatively strongly predisposing factors associated with cervical spondylotic disease are frequent lifting of heavy objects, cigarette-smoking, and frequent diving from a board (5). There was no identifiable predisposing factor in our patient.

The clinical presentation in a spondylotic patient is usually subacute to chronic progressive radiculopathy or myeloradiculopathy. An acute presentation resulting in extrusion of the disc is known to occur in trauma to the cervical spine and frequently presents with quadriparesis or paraparesis. A spontaneous extrusion of cervical disc along with an intradiscal hematoma presenting with unilateral spinal cord compression is rare. The exact mechanism of such an event is unknown. There was no demonstrable coagulopathy or vascular anomaly in our patient nor there any antecedent history of trauma. A sudden increase in the fragile epidural veins with dissection of the hematoma into a pre-existing prolapsed intervertebral disc tissue is postulated (7).

On MR imaging, the prolapsed or extruded intervertebral disc usually depicts an iso- to hypointense signal on T1- and T2-weighted images, primarily due to loss of water content within the intervertebral disc tissue $(4,9)$. It can be central or posterolateral in position. In our patient, the hypointense signal within the lesion on T1-weighted images was unusual suggesting bleed within the lesion. The presence of a bleed within an extradural lesion in the cervical spine should alert the clinician to the possibility of an intradiscal hematoma within an extruded intervertebral disc. 


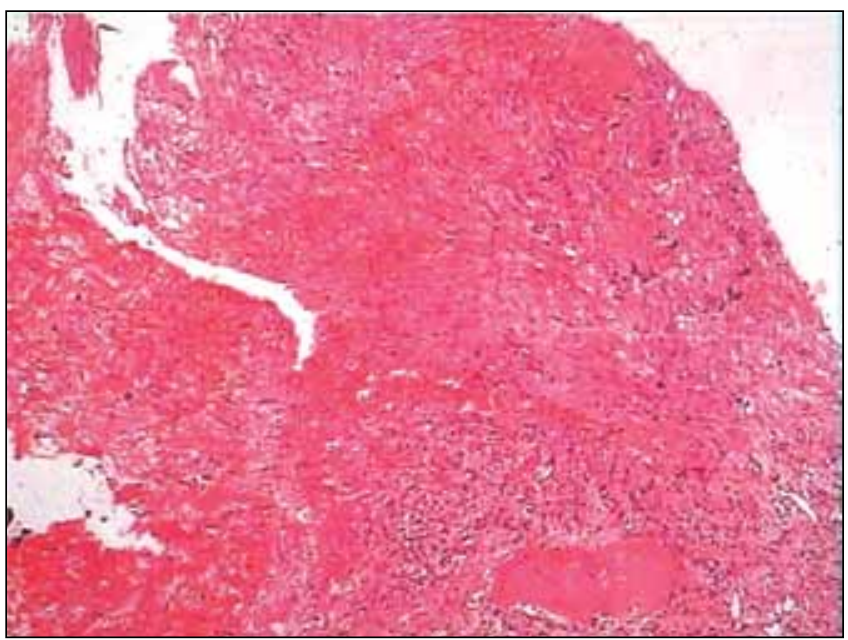

Figure 3: Photomicrograph of the intervertebral disc showing degeneration and hematoma. HE stain, X20.

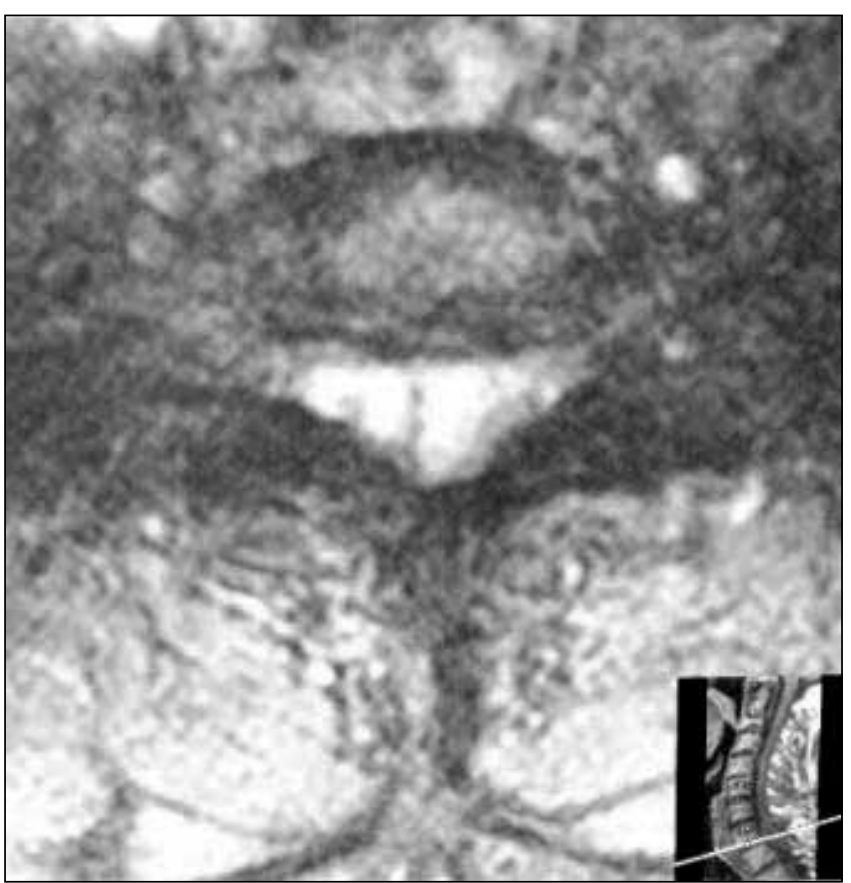

Figure 4: T2 axial image showing complete excision of the disc with restoration of subarachnoid space.

Symptomatic prolapsed or extruded cervical intervertebral disc are usually anteriorly located and an anterior approach for decompression is preferred. In our case, since the lesion was predominantly posterolateral in location and presented unlike a prolapsed intervertebral disc, a posterior approach was preferred. As soon as lesion was incised, there was egress of dark red clot. Subsequently, the intervertebral disc was removed piecemeal in its entirety.

In conclusion, extrusion of intervertebral disc at C7-D1 level in an elderly patient is rare. The occurrence of an intradiscal hematoma with an extruded intervertebral disc has hitherto never been reported. The presence of a hypointensity within an extruded cervical intervertebral disc on MR imaging can mimic a spontaneous epidural hematoma or a bleed within tumor. It should alert the clinician to the possibility of a bleed within the intervertebral disc. A posterior approach for a predominantly posterolateral extrusion of intervertebral disc at C7-D1 level seems plausible.

\section{REFERENCES}

1. Adams $C B$, Logue $V$ : Studies in cervical spondylotic myelopathy. I. Movement of cervical roots, dura \& cord, and their relation to the course of the extrathecal roots. Brain 94: 557-568, 1971

2. Bohlman HH, Emery SE: The pathophysiology of cervical spondylosis and myelopathy. Spine 13: 843-846, 1988

3. Connell MD, Wiesel SW: Natural history and pathogenesis of cervical disc disease. Orthop Clin N Am 23: 369-380, 1992

4. Jackson RJ, Gokaslan ZL: Treatment of disc and ligamentous diseases of cervical spine. In Winn HR, (ed). Youman's Neurological surgery. 5thed, Vol 4. Philadelphia: Saunders, 2004: 4395-4407

5. Kelsey JL, Githens PB, Walter SD, Southwick WO, Weil U, Holford TR, Ostfeld AM, Calogero JA, O'Connor T, White AA 3rd: Epidemiological study of acute prolapsed cervical intervertebral disc. J Bone Joint Surg 66:907-914, 1984

6. Keyes D, Compere E: The normal and pathological physiology of the nucleus pulposus of the intervertebral disc: An anatomical, clinical and experimental study. J Bone Joint Surg 14:897-938, 1932

7. KuboY, Waga S, Kojima T, Matsubara T, Kuga Y, Nakagawa Y: Microsurgical anatomy of the lower cervical spine and cord. Neurosurg 34:895-902, 1994

8. Miyakoshi N, Hongo M, Kasukawa Y, Ando S, Shimada Y: Thoracic disc herniation with hematoma: A case report. Neurol Med Chir (Tokyo) 48: 414-417, 2008

9. Post NH, Cooper PR, Frempong-Boadu AK, Costa ME: Unique features of herniated discs at cervicothoracic junction: Clinical presentation, imaging, operative management, and outcome after anterior decompressive operation in 10 patients. Neurosurgery 58: 497-501, 2006

10. Stavrinou LC, Stranjalis G, Maratheftis N, Bouras T, Sakas DE: Cervical disc, mimicking nerve sheath tumor, with rapid spontaneous recovery: A case report. Eur Spine J 18:176-178, 2009 